\title{
PENGARUH PROMOSI PENJUALAN TERHADAP KEPUTUSAN KONSUMEN MENGINAP DI HOTEL THE PREMIERE PEKANBARU
}

\author{
Teuku Reza Kurniawan \\ Sekolah Tinggi Ilmu Ekonomi Riau \\ E-mail: teukurezhakurniawan@ gmail.com
}

\begin{abstract}
The purpose of this study is to determine the effect of Sales Promotion on Consumer Decisions to Stay at The Premiere Hotel Pekanbaru. Because sales promotion is one of the main factors supporting the success of a company to market its products, in addition to being seen from how consumers' decisions in determining their choices. The population in this study was 64,738 consumers who stayed at The Premiere Hotel Pekanbaru. Thus the number of samples is 100 consumers. From the results of the analysis formulated a simple linear regression equation with the equation $Y=12.050+$ $0.733 X$. Where, the constant is 12,050 , meaning that if the independent variable $X$ (sales promotion) value is 0 , then the dependent variable $Y$ (consumer's decision) is 12,050. The variable regression coefficient $X$ (sales promotion) of 0.733 means that if the sales promotion has increased by 1 point, then the consumer's decision will also increase by 0.733. Positive coefficient means that there is a positive relationship between sales promotions with consumer decisions. The higher the sales promotion, the consumer's decision will increase. The test results of the significant test (t), obtained tcount of 8.885 is greater than $t$ table with a ttable value of 1.984, with a significance level of 0.000 $<0.05$. Thus it means that the sales promotion variable $(X)$ significantly influences the purchase decision variable $(Y)$. So it can be concluded that the sales promotion has a significant effect on consumer decisions to stay at The Premiere Hotel Pekanbaru. R square values (R2) of 0.446 or $44.6 \%$ were obtained. This shows that changes in the value of consumer decisions are influenced by changes in the value of the free variable sales promotion by $44.6 \%$ while $55.4 \%$ is determined by other variables that are not in this research model.
\end{abstract}

Keywords: Sales Promotion, Consumer Decisions

\section{A. PENDAHULUAN}

Pada saat ini industri pariwisata Indonesia mengalami perkembangan yang sangat pesat dan menjadi sektor yang tidak pernah habisnya, karena selain merupakan penghasil devisa negara, jika dikelola dengan baik dan terarah dapat meningkatkan taraf hidup masyarakat dari segi ekonomi. Hal ini perlu mendapatkan perhatian khusus sebagai peluang bisnis dalam perekonomian Indonesia selain faktor-faktor lain seperti industri-industri kecil dan menengah dalam mendongkrak perekonomian nasional yang terpuruk akibat krisis moneter. Kesadaran akan perlunya penanganan yang lebih serius terhadap bidang ini telah melahirkan beberapa kebijakan sebagai langkah pengembangannya. Oleh karena itu pemasaran pariwisata akan menjadi konsep penting yang harus dipegang dan dilaksanakan dalam membina, mempertahankan serta memupuk pertumbuhan yang diharapkan dalam bidang pariwisata sebagai program utama pengembangan daerah wisata khususnya di Propinsi Riau.
Kegiatan kepariwisataan yang membutuhkan sarana penunjang seperti transportasi dan akomodasi. Salah satu sarana penting dalam industri pariwisata khususnya untuk memenuhi kebutuhan orang yang bepergian lebih dari sehari adalah hotel. Dan pada saat ini persaingan dalam bisnis perhotelan semakin ketat, dikarenakan banyak berdiri hotel-hotel baru. Hal ini bisa jadi dipengaruhi oleh adanya kebijakan pemerintah yang memberikan kelonggaran dalam bidang perhotelan, terlebih dengan dicanangkan Tahun 1991 sebagai Tahun kunjungan ASEAN yang berarti kebutuhan akan jasa akomodasi meningkat dan akan mempengaruhi kebutuhan jasa perhotelan.

Usaha perhotelan adalah salah satu komponen industri pariwisata yang memiliki peranan besar di Indonesia. Dilihat dari fungsi utamanya, produk utama yang dijual oleh usaha perhotelan adalah jasa penginapan. Sejalan dengan perkembangan tersebut maka jika sebelumnya produk atau jasa utama sebuah hotel yang menjadi kebutuhan utama wisatawan adalah kamar atau penginapan 
sekarang mengalami perkembangan. Konsumen mengharapkan sesuatu yang bukan hanya sekedar kamar menginap, namun mereka lebih mengharapkan hal lain seperti pelayanan, kondisi lingkungan yang menyenangkan, sopan santun dan rasa hormat dari seluruh karyawannya. Ini akan menimbulkan persaingan yang didasarkan pada upaya untuk memenangkan pasar, yaitu khalayak pengguna jasa hotel yang menginap di hotel untuk maksud tertentu. Dibutuhkan upaya maksimal yang dapat menarik minat konsumen untuk memilih menginap di hotel yang dipandangnya dapat memberi kenyamanan, serta dapat menyediakan apa yang menjadi kebutuhannya, sebab jika tidak maka konsumen dapat mencari alternatif hotel lain yang sejenis yang dapat memenuhi kebutuhannya.

Berikut data jumlah kamar yang tersedia pada perusahaan jasa Hotel The Premiere Pekanbaru tahun 2013 sampai dengan tahun 2017 dapat dilihat pada tabel 1 di bawah ini:

Tabel. 1

Jumlah Kamar yang Tersedia di Hotel

Premiere Pekanbaru Tahun 2013-2017

\begin{tabular}{|l|l|}
\hline Jenis Kamar & $\begin{array}{l}\text { Jumlah } \\
\text { Kamar }\end{array}$ \\
\hline Superior Twin & 75 \\
\hline Superior Double & 60 \\
\hline Executive Twin & 7 \\
\hline Executive Double & 7 \\
\hline Executive Deluxe & 10 \\
\hline Junior Suite & 4 \\
\hline President Suite & 1 \\
\hline Penthouse Hotel Premiere \\
Sumber: Marketing \\
Pekanbaru
\end{tabular}

Pada tabel 1 dapat dilihat, jenis kamar superior twin berjumlah 75 kamar, superior double berjumlah 60 kamar, executive twin berjumlah 7 kamar, executive double berjumlah 7 kamar, executive deluxe berjumlah 10 kamar, junior suite berjumlah 4 kamar, president suite berjumlah 1 kamar, dan penthouse berjumlah 4 kamar.

Kegiatan promosi yang dilakukan hotel The Premiere Pekanbaru bisa dilakukan saat jam kerja, waktu-waktu di luar week end, hari libur sekolah atau libur umum, serta

Eko dan Bisnis (Riau Economics and Business Reviewe) Volume 11, Nomor 1, 27 Maret 2020 pada saat adanya kunjungan kerja baik dari pihak pemerintah, BUMN, partai, atau pun perusahaan-perusahaan swasta.

Strategi yang digunakan oleh sebuah hotel memiliki peranan yang sangat penting. Hotel harus dapat memberikan informasi yang benar dengan memanfaatkan proses komunikasi dengan semua pihak seperti kepada tamu, pemasok seperti agen penjual sayur mayur yang menjadi pendistribusi langsung ke hotel, pengecer seperti travel agent, dan pihakpihak lain yang memiliki kepentingan terhadap perusahaan (hotel). Cara yang sering digunakan oleh pemasar agar dapat menarik perhatian tamu yaitu melalui kegiatan promosi. Adanya kegiatan promosi dapat memberikan informasi kepada tamu mengenai berbagai hal tentang hotel yang bersangkutan mulai dari fasilitas yang dimiliki, room rate, lokasi hotel sampai dengan berbagai penawaran yang sedang ditawarkan hotel.

Promosi merupakan suatu alat komunikasi pemasaran yang berusaha untuk menyebarkan informasi, mempengaruhi atau membujuk dan mengingatkan tamu pada produk yang dimiliki hotel. Promosi memiliki lima bauran promosi atau yang biasa dikenal dengan promotion mix yaitu periklanan (advertising), penjualan perorangan (personal selling), promosi penjualan (sales promotion), hubungan masyarakat (public relations), dan pemasaran langsung (direct marketing).

Salah satu bentuk promosi yang digunakan dalam industri jasa perhotelan adalah promosi penjualan (sales promotion) yang merupakan insentif jangka pendek untuk mendorong pembelian atau penjualan dari suatu produk atau jasa. Hotel Premiere Pekanbaru merupakan salah satu hotel yang bertaraf Internasional dan salah satu Hotel berbintang empat + yang ada di kota Pekanbaru yang tentunya memiliki strategi promosi penjualan untuk meningkatkan kunjungan tamu dan volume penjualan kamar hotelnya serta produk jasa lainnya. Di mana mayoritas tamu yang datang P.ISSN: 1410-7988 E.ISSN: 2614-123X 
menginap dengan tujuan bisnis sehingga diperlukan tata cara praktis dan cepat dalam pelayanan serta fasilitas bisnis sebagai penunjang.

Program promosi penjualan yang telah dilakukan oleh Hotel The Premiere Pekanbaru diantaranya menjalin hubungan kerja dengan perusahaan atau travel agent terkait sehingga terjalin suatu kesepakatan mengenai harga (corporate rate) yang akan dikenakan kepada perusahaan yang bersangkutan apabila menginap di Hotel The Premiere Pekanbaru, selain itu Hotel The Premiere Pekanbaru juga memberikan diskon selama beberapa periode tertentu kepada pelanggan yang menggunakan jenis credit card yang menjalin kerjasama dengan pihak Hotel The Premiere Pekanbaru. Hal ini tentu sesuai dengan kesepakatan yang telah dibuat sebelumnya antara pihak perusahaan dengan pihak sales and marketing department Hotel The Premiere Pekanbaru.

Berikut data kegiatan promosi penjualan yang dilakukan perusahaan Hotel The Premiere Pekanbaru dari tahun 2013 sampai dengan 2017 dapat dilihat pada tabel 1.3 di bawah ini

Tabel. 2

Media Promosi Hotel The Premiere Pekanbaru

\begin{tabular}{|c|c|c|}
\hline Tahun & Bauran Promosi & Media Promosi \\
\hline \multirow{3}{*}{2013} & \multirow{3}{*}{$\begin{array}{l}\text { Promosi } \\
\text { penjualan }\end{array}$} & Corporate Rates \\
\hline & & Kontrak Rates \\
\hline & & Spesial Rates \\
\hline \multirow{3}{*}{2014} & \multirow{3}{*}{$\begin{array}{l}\text { Promosi } \\
\text { penjualan }\end{array}$} & Corporate Rates \\
\hline & & Kontrak Rates \\
\hline & & Spesial Rates \\
\hline \multirow{3}{*}{2015} & \multirow{3}{*}{$\begin{array}{l}\text { Promosi } \\
\text { penjualan }\end{array}$} & Corporate Rates \\
\hline & & Kontrak Rates \\
\hline & & Spesial Rates \\
\hline \multirow{3}{*}{2016} & \multirow{3}{*}{$\begin{array}{l}\text { Promosi } \\
\text { penjualan }\end{array}$} & Corporate Rates \\
\hline & & Kontrak Rates \\
\hline & & Spesial Rates \\
\hline \multirow{3}{*}{2017} & \multirow{3}{*}{$\begin{array}{l}\text { Promosi } \\
\text { penjualan }\end{array}$} & Corporate Rates \\
\hline & & Kontrak Rates \\
\hline & & Spesial Rates \\
\hline
\end{tabular}

Sumber: Marketing Hotel Premiere Pekanbaru

Dari tabel 2 di atas dapat dilihat media promosi yang digunakan oleh Hotel Premiere Pekanbaru untuk menarik tamu

Eko dan Bisnis (Riau Economics and Business Reviewe) Volume 11, Nomor 1, 27 Maret 2020 agar menginap di Hotel Premiere yaitu dengan memberikan potongan-potongan harga kamar khusus diantaranya adalah : Corporate Rates yaitu harga kamar khusus yang diberikan kepada instansi-instansi pemerintah, BUMN, atau perusahaanperusahaan swasta yang sering menggunakan fasilitas hotel. Kontrak Rates yaitu harga kamar khusus yang diberikan kepada Travel Agent (Agent Perjalanan), Airlines yang dijadikan sebagai mitra kerja dalam pemasaran Hotel The Premiere Pekanbaru. Spesial Rates yaitu harga kamar khusus yang diberikan kepada pelanggan yang telah menginap cukup lama di hotel The Premiere Pekanbaru.

\section{TINJAUAN PUSTAKA Pengertian Bauran Pemasaran}

Bauran promosi merupakan gabungan dari berbagai jenis promosi yang ada untuk suatu produk yang sama agar hasil dari kegiatan promosi yang dilakukan dapat memberikan hasil yang maksimal.

Jenis promosi atau promotional mix menurut William J. Stanton (dalam Hendra Saputra, 2008:23) adalah kombinasi strategi yang paling baik dari variabel-variabel periklanan, personal celling, dan alat promosi lain yang semuanya direncanakan untuk mencapai tujuan program penjualan. Definisi tersebut tidak menyebutkan secara jelas beberapa variabel promotion mix serta periklanan dan personal selling.

Menurut Kotler dan Amstrong (2006:124) variabel-variabel yang ada di dalam Promotion Mix ada lima yaitu :

a. Periklanan (Advertising). Segala biaya yang harus dikeluarkan sponsor untuk melakukan presentasi dan promosi non pribadi dalam bentuk gagasan, barang dan jasa.

b. Penjualan Personal (Personal Selling). Presentasi pribadi oleh para wiraniaga perusahaan dalam rangka mensukseskan penjualan dan membangun hubungan dengan pelanggan.

c. Promosi Penjualan (Sales Promotion). Insentif jangka pendek untuk

P.ISSN: 1410-7988 E.ISSN: 2614-123X 
mendorong pembelian atau penjualan suatu produk atau jasa.

d. Hubungan Masyarakat (Public Relation). Membangun hubungan baik dengan publik terkait untuk memperoleh dukungan, membangun "citra perusahaan" yang baik dan menangani atau menyingkirkan gosip, cerita dan peristiwa yang dapat merugikan.

e. Pemasaran Langsung (Direct Marketing). Komunikasi langsung dengan pelanggan yang diincar secara khusus untuk memperoleh tanggapan langsung. Dengan demikian maka promosi merupakan kegiatan perusahaan yang dilakukan dalam rangka memperkenalkan produk kepada konsumen sehingga dengan kegiatan tersebut konsumen tertarik untuk melakukan pembelian.

\section{Promosi Penjualan}

Menurut Kolter dan Armstrong (2008:204) promosi penjualan adalah insentif jangka pendek untuk mendorong penjualan produk atau jasa. Menurut Fandy Tjiptono (2008:546), promosi penjualan merupakan segala bentuk penawaran atau insentif jangka panjang yang ditujukan bagi pembeli, pengecer atau pedagang grosir dan dirancang untuk memperoleh respon spesifik dan segera. Sedangkan menurut pendapat Kotler dan Armstrong (2004:660), menyatakan bahwa: "Promosi penjualan adalah insentifinsentif jangka pendek untuk mendorong pembelian atau penjualan produk atau jasa".

\section{Indikator Promosi Penjualan}

Selain Memperharikan alat-alat promosi penjualan perusahaan harus bisa memilih indikator-indikator promosi penjualan yang tepat dalam mempromosikan produk. Menurut Kotler \& Keller (2007:272) diantaranya:

1. Frekuensi Promosi. Adalah jumlah promosi penjualan yang dilakukan dalam suatu waktu melalui media promosi penjulan

Eko dan Bisnis (Riau Economics and Business Reviewe) Volume 11, Nomor 1, 27 Maret 2020
2. Kualitas Promosi. Adalah tolak ukur seberapa baik promosi penjulan dilakukan.

3. Kuantitas Promosi. Adalah nilai atau jumlah promosi penjualan dilakukan perusahaan

4. Waktu Promosi. Adalah lamanya promosi yang dilakukan oleh perusahaan

5. Ketepatan atau kesesuaian sasaran promosi merupakan factor yang diperlukan untuk mencapai target yang diiginkan perusahaan.

\section{Keputusan Konsumen}

Keputusan konsumen merupakan suatu tindakan dari dua atau lebih pilihan alternatif, Mengenai proses, cara, perbuatan membeli, dengan memertimbangkan faktor lain tentang apa yang dibeli, waktu membeli, dimana membelinya serta cara pembayarannya.

Sumarwan (2004:310) menyebutkan tiga tipe pengambilan keputusan konsumen: a. Pemecahan masalah yang diperluas. Ketika konsumen tidak memiliki kriteria untuk mengevaluasi sebuah kategori produk atau merek tertentu pada kategori tersebut, atau tidak membatasi jumlah merek yang akan dipertimbangkan ke dalam jumlah yang mudah di evaluasi, maka pengambilan keputusannya bisa disebut sebagai pemecahan masalah yang diperluas.

b. Pemecahan masalah yang terbatas. Pada tipe keputusan ini, konsumen telah memiliki kriteria dasar untuk mengevaluasi kategori produk dan berbagai merek pada kategori tersebut, namun konsumen belum memiliki preferensi merek tertentu.

c. Pemecahan Masalah Rutin. Konsumen telah memiliki pengalaman terhadap produk yang akan dibelinya. Konsumen juga telah memiliki standan untuk mengevaluasi merek. Konsumen seringkali hanya mereview apa yang telah diketahuinya.

Untuk memahami pembuatan keputusan konsumen, terlebih dahulu harus 
dipahami sifat-sifat keterlibatan konsumen dengan produk atau jasa (Sutisna,2003:11). Memahami tingkat keterlibatan konsumen terhadap produk atau jasa berarti pemasar berusaha mengidentifikasi hal-hal yang menyebabkan seseorang merasa harus terlibat atau tidak dalam pembelian suatu produk atau jasa. Tingkat keterlibatan konsumen dalam suatu pembelian dipengaruhi oleh stimulus (rangsangan). Dengan perkataan lain, apakah seseorang mersa terlibat atau tidak terhadap suatu produk ditentukan apakah dia merasa penting atau tidak dalam pengambilan keputusan pembelian produk atau jasa. Oleh karena itu, bisa dikatakan bahwa ada konsumen yang mempunyai keterlibatan tinggi dalam pembelian suatu produk atau jasa, dan ada juga konsumen yang mempunyai keterlibatan yang rendah atas pembelian produk jasa.

\section{Indikator Keputusan Konsumen}

Ada lima tahapan perilaku konsumen dalam mengambil keputusan pembelian menurut Kotler \& Keller dalam (Zulaica \& Irawati, 2016:126-127), yaitu:

1. Pengenalan kebutuhan Pengenalan kebutuhan muncul ketika konsumen menghadapi suatu masalah, yaitu suatu keadaan dimana terdapat perbedaan antara keadaan yang diinginkan dan keadaan yang sebenarnya terjadi.

2. Pencari informasi Pencari informasi mulai dilakukan ketika konsumen memandang bahwa kebutuhan tersebut bisa dipenuhi dengan membeli dan mengonsumsi produk. Konsumen akan mencari informasi yang tersimpan dalam ingatannya (pencarian internal) dan mencari informasi dari luar (pencarian eksternal).

3. Evaluasi alternatif Evaluasi alternatif adalah proses mengevaluasi pilihan produk dan merek, dan memilihnya sesuai dengan keinginan konsumen. Pada proses ini konsumen membandingkan berbagai merek pilihan yang dapat memberikan manfaat kepadanya serta masalah yang dihadapinya.

Eko dan Bisnis (Riau Economics and Business Reviewe) Volume 11, Nomor 1, 27 Maret 2020
4. Keputusan pembelian Setelah tahaptahap di atas dilakukan, pembeli akan menentukan sikap dalam pengambilan keputusan apakah membeli atau tidak. Jika memilih untuk membeli produk, dalam hal ini konsumen dihadapkan pada beberapa alternatif pengambilan keputusan seperti produk, merek, penjual, tempat, harga, penjual, kuantitas dan waktu.

5. Hasil Setelah membeli suatu produk, konsumen akan mengalami beberapa tingkat kepuasan dan ketidakpuasan. Tahap ini dapat memberkan informasi yang penting bagi perusahaan apakah produk dan pelayanan yang telah dijual dapat memuaskan konsumen atau tidak.

\section{Pengaruh Promosi Penjualan Terhadap Keputusan Konsumen}

Promosi Penjualan memberikan dorongan emosional yang luar biasa bagi konsumen untuk membeli (Hermawan, 2012:129). Dalam situasi persaingan bisnis yang tinggi dimana konsumen mempunyai banyak pilihan tempat berbelanja ataupun tempat menginap, promosi penjualan yang baik akan membuat konsumen berhenti sejenak, membuat mereka berfikir tentang sebuah tempat berbelanja ataupun tempat untuk menginap, dan bila pengaruh yang ditimbulkan tepat akan mengalihkan konsumen, sehingga membuat konsumen memutuskan untuk mengikuti promosi penjualan yang ditawarkan.

Konsumen pada umumnya terbuka terhadap banyak ransangan yang diterima melalui panca indra, dan ransangan tersebut dapat menarik perhatian konsumen akan keberadaan sebuah tempat berbelanja ataupun tempat menginap. Oleh karena itu pelaku usaha harus dapat memberikan ransangan yang dapat menarik perhatian konsumen melalui alat-alat promosi penjualan. Menurut Kotler (2005:299) bahwa perusahaan menggunakan alat-alat promosi penjualan untuk mendapatkan tanggapan pembeli yang lebih kuat dan lebih cepat. Seluruh alat-alat promosi

\footnotetext{
P.ISSN: 1410-7988 E.ISSN: 2614-123X
} 
penjualan dapat berpengaruh terhadap keputusan pembelian konsumen.

\section{METODE}

\section{Lokasi Penelitian}

Penelitian ini di laksanakan pada Hotel Premiere, Jalan Jendral Sudirman No. 389 Pekanbaru.

\section{Jenis dan Sumber Data Data Primer}

Data primer adalah data yang dikumpulkan secara langsung oleh peneliti untuk menjawab masalah atau tujuan penelitian yang dilakukan dalam penelitian eksploratif, deskriptif maupun kausal dengan menggunakan metode pengumpulan data berupa survey ataupun observasi (Hermawan, 2013:211).

\section{Data Sekunder}

Data sekunder adalah struktur data historis mengenai variabel-variabel yang telah dikumpulkan dan dihimpun sebelumnya oleh pihak lain. Sumber data sekunder bisa diperoleh dari dalam suatu perusahaan (sumber internal), berbagai internet websites, perpusatakaan umum maupun lembaga pendidikan, membeli dari perusahaanperusahaan yang memang mengkhususkan diri untuk menyajikan data sekunder dan lain-lain (Hermawan, 2013:211-212).

\section{Populasi}

Menurut Suhasimi Arikunto (2010:173) Populasi adalah keseluruhan subyek penelitian. Jadi pengertian populasi secara umum yaitu bukan hanya sekedar jumlah yang ada pada pokok obyek/subyek yang akan dipelajari, tetapi meliputi keseluruhan darai karakteristik atau sifat yang dimiliki oleh subyek yang akan diteliti.

Adapun yang menjadi populasi dalam penelitian ini adalah Konsumen yang menginap di Hotel The Premiere Pekanbaru yaitu 64.738 konsumen.

\section{Sampel}

Sampel adalah sebagian atau wakil dari populasi yang diteliti. Teknik pengambilan sampel dalam penelitian ini menggunakan teknik Simple Random Sampling, yaitu pengambilan sampel dengan cara acak sederhana melalui daftar bilangan random, sehingga setiap elemen populasi mempunyai kesempatan yang sama untuk terpilih menjadi anggota sampel yang diteliti, (Supranto, 2009:75).

Cara atau pedoman didalam menentukan sampel menurut pendapat Slovin dalam buku metodologi riset bisnis Roni Andespa:

$\mathrm{n}=\frac{N}{1+N e^{2}}$

Keterangan :

$\mathrm{n}=$ Besar sampel dalam penelitian

$\mathrm{N}=$ Besar populasi dalam penelitian

$\mathrm{e}=$ error atau tingkat kesalahan dalam pengambilan sampel (10\%)

$\mathrm{n}=\frac{N}{1+N e^{2}}$

$\mathrm{n}=\frac{64.738}{1+64.738 \times 0,01}$

$\mathrm{n}=\frac{64.738}{1+647,38}$

$\mathrm{n}=\frac{64.738}{648.38}$

$\mathrm{n}=99,84$

$\mathrm{n}=100$ (dibulatkan)

Konsumen yang melakukan keputusan menginap pada Hotel The Premiere Pekanbaru, Berdasarkan rumus Slovin di atas maka sampel yang akan digunakan dalam penelitian ini adalah 99,84 outlet yang kemudian dibulatkan menjadi 100 outlet atau konsumen yang menjadi sampel dalam penelitian ini.

\section{Analisis Data}

Teknik analisa yang digunakan adalah teknik analisa deskriptif dan kuantitatif. Teknik deskriptif adalah suatu analisis dengan cara mengelompokkan data yang sedemikian rupa, kemudian menghubungkannya dengan teori-teori yang berkaitan dengan permasalahan yang dihadapi oleh perusahaan sehingga dapat diambil suatu kesimpulan, sedangkan teknik kuantitatif adalah metode penelitian yang kemudian diubah dan dianalisa untuk diambil kesimpulannya menurut (Suharismi Arikunto, 2010 : 282). 
HASIL

\section{Metode Deskriptif}

Hasil dari rekapitulasi jawaban responden tentang Promosi Penjualan (X) memperoleh nilai rata-rata 4,56 dan hasil dari rekapitulasi jawaban responden mengenai Keputusan Konsumen (Y) memperoleh nilai 4,55 ini menunjukkan bahwa kriteria jawaban responden sangat baik/sangat setuju dengan pernyataan-pernyataan yang telah diajukan.

\section{Metode Kuantitatif \\ Uji Regeresi Linier Sederhana}

Regresi linear sederhana dugunakan untuk mengetahui pengaruh variabel bebas promosi penjualan (X) terhadap variabel terikat keputusan konsumen (Y). Adapun hasil dari pengujian regresi linear sederhana yang dapat dilihat pada tabel dibawah ini.

\section{Tabel 3}

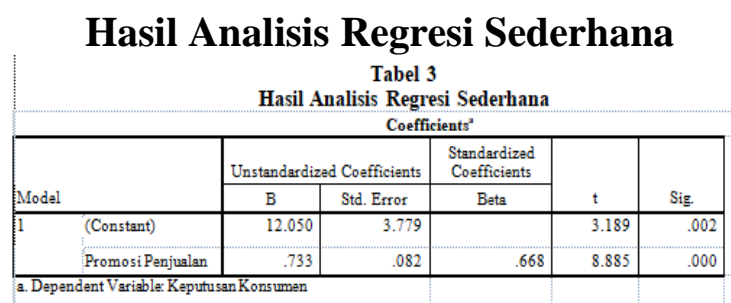

Sumber : Hasil Olahan SPSS, 2018 berikut:

Persamaan regresinya adalah sebagai

$\mathrm{Y}=\mathrm{a}+\mathrm{bX}$

$Y=12,050+0,733 X$

Persamaan regresi linear sederhana diatas, dapat dijelaskan sebagai berikut:

a. Nilai konstanta (a) $=12,050$; artinya jika variabel bebas $\mathrm{X}$ (promosi penjualan) nilai skalanya adalah 0 , maka variabel terikat $\mathrm{Y}$ (keputusan konsumen) sebesar 12,050.

b. Koefisien regresi $\mathrm{b}=0,733$; jika promosi penjualan mengalami kenaikan sebesar 1 poin, maka keputusan konsumen juga akan mengalami kenaikan sebesar 0,733. Koefisien bernilai positif artinya terjadi hubungan positif antara promosi penjualan dengan keputusan konsumen. Semakin tinggi promosi penjualan maka keputusan konsumen semakin meningkat.

Eko dan Bisnis (Riau Economics and Business Reviewe) Volume 11, Nomor 1, 27 Maret 2020

\section{Uji Hipotesis}

Uji t

Apabila $t_{\text {hitung }}>t_{\text {tabel, }}$ maka hipotesis diterima dengan kata lain variabel independen secara individual memiliki pengaruh yang signifikan terhadap variabel dependen. Begitu juga sebaliknya, jika $t_{\text {hiutng }}<t_{\text {tabel }} \quad$ maka hipotesis ditolak, (Ghozali, 2006:151).

Berdasarkan hasil olahan SPSS pada tabel 3 diatas, bahwa dari pengujian hipotesis yang dilakukan untuk variabel promosi penjualan $(\mathrm{X})$ diperoleh nilai $\mathrm{t}_{\text {hitung }}$ sebesar 8,885 lebih besar dari t tabel dengan nilai $t_{\text {tabel }}$ sebesar 1,984 , dengan tingkat signifikansi sebesar $0,000<0,05$. Hal ini berarti Ho ditolak dan Ha diterima. Dengan demikian berarti variabel promosi penjualan (X) secara parsial berpengaruh signifikan terhadap variabel keputusan konsumen (Y). Sehingga dapat disimpulkan bahwa promosi penjualan berpengaruh signifikan terhadap keputusan kosumen menginap di Hotel The Premiere Pekanbaru.

\section{Koefisien Determinasi $\left(\mathbf{R}^{2}\right)$}

Nilai koefisien determinasi $R$ Square $\left(\mathrm{R}^{2}\right)$ digunakan untuk mengetahui seberapa besar persentase pengaruh variabel promosi penjualan terhadap variabel keputusan konsumen menginap di Hotel The Premiere Pekanbaru.

Adapun hasil dari koefisien determinasi yang dapat dilihat pada tabel berikut:

\section{Tabel 4}

Hasil Uji Koefisien Determinasi $\left(\mathbf{R}^{2}\right)$ Model Summary ${ }^{b}$

\begin{tabular}{|l|l|l|l|l|}
\hline Model & $R$ & R Square & $\begin{array}{l}\text { Adjusted R R } \\
\text { Square }\end{array}$ & $\begin{array}{l}\text { Std. Error of } \\
\text { the Estimate }\end{array}$ \\
\hline 1 & $.668^{\mathrm{a}}$ & .446 & .441 & 3.353 \\
\hline
\end{tabular}

a. Predictors: (Constant), Promosi Penjualan

b. Dependent Variable: Keputusan Konsumen

Sumber : Hasil Olahan SPSS, 2018

Berdasarkan hasil uji koefisien determinasi pada tabel 5.39 diatas, diperoleh nilai $\mathrm{R}$ square $\left(\mathrm{R}^{2}\right)$ sebesar 0,446 atau 44,6\%. Hal ini menunjukkan bahwa perubahan nilai

P.ISSN: 1410-7988 E.ISSN: 2614-123X 
keputusan konsumen dipengaruhi oleh perubahan nilai variabel bebas promosi penjualan sebesar $44,6 \%$ sedangkan $55,4 \%$ ditentukan oleh variabel lain yang tidak ada dalam model penelitian ini.

\section{SIMPULAN}

Berdasarkan hasil analisis dan pembahasan yang telah dipaparkan diatas, maka dapat disimpulkan :

1. Hasil dari rekapitulasi jawaban responden tentang Promosi Penjualan (X) memperoleh nilai rata-rata 4,56 dan hasil dari rekapitulasi jawaban responden mengenai Keputusan Konsumen (Y) memperoleh nilai 4,55 ini menunjukkan bahwa kriteria jawaban responden sangat baik/sangat setuju dengan pernyataan-pernyataan yang telah diajukan.

2. Penelitian ini menggunakan model persamaan regresi linear sederhana dengan persamaan $\mathrm{Y}=12,050+0,733 \mathrm{X}$ Persamaan ini dapat diartikan sebagai berikut:

- Konstanta sebesar 12,050, artinya jika variabel bebas $\mathrm{X}$ (promosi penjualan) nilainya 0 , maka variabel terikat Y (keputusan konsumen) sebesar 12,050

- Koefisien regresi variabel X (promosi penjualan) sebesar 0,733 artinya jika promosi penjualan mengalami kenaikan sebesar 1 poin, maka keputusan konsumen juga akan mengalami kenaikan sebesar 0,733 . Koefisien bernilai positif artinya terjadi hubungan positif antara promosi penjualan dengan keputusan konsumen. Semakin tinggi promosi penjualan maka keputusan konsumen semakin meningkat.

3. Hasil pengujian uji signifikan (t), diperoleh nilai $t_{\text {hitung }}$ sebesar 8,885 lebih besar dari $t$ tabel dengan nilai $t_{\text {tabel }}$ sebesar 1,984, dengan tingkat signifikansi sebesar $0.000<0.05$. Dengan demikian berarti variabel promosi penjualan $(\mathrm{X})$ berpengaruh signifikan terhadap variabel keputusan

Eko dan Bisnis (Riau Economics and Business Reviewe) Volume 11, Nomor 1, 27 Maret 2020 pembelian (Y). Sehingga dapat disimpulkan bahwa promosi penjualan berpengaruh signifikan terhadap keputusan konsumen menginap di Hotel The Premiere Pekanbaru.

Diperoleh nilai $\mathrm{R}$ square $\left(\mathrm{R}^{2}\right)$ sebesar 0,446 atau $44,6 \%$. Hal ini menunjukkan bahwa perubahan nilai keputusan konsumen dipengaruhi oleh perubahan nilai variabel bebas promosi penjualan sebesar $44,6 \%$ sedangkan $55,4 \%$ ditentukan oleh variabel lain yang tidak ada dalam model penelitian ini.

\section{DAFTAR RUJUKAN}

Ali, Hasan. 2013. Marketing dan KasusKasus Pilihan. Yogyakarta. CAPS (Center For Academic Publishing Service).

Andespa, Roni. 2012. Metodologi Riset Bisnis. Pekanbaru, Al Huda Press.

Arikunto, Suharsimi, 2010. Prosedur Penelitian Suatu Pendekatan Praktek . Jakarta. Rineke Cipta.

Ashari, Purbayu Budi Santoso. 2005. Analisis statistic dengan Microsoft exel dan SPSS. Yogyakarta.

Buchari, Alma. 2002. Manajemen Pemasaran dan Pemasaran Jasa. Bandung: Alfabeta.

Buchari, Alma. 2007. Manajemen Pemasaran dan Pemasaran Jasa. Bandung: Alfabeta.

Ghozali, Imam. 2005. Analisis Multivariate Dengan Program SPSS. Badan Penerbit Universitas Diponegoro. Semarang.

Griffin, Ricky W dan Ebert, Ronald J. 2008. Bisnis.Edisi 8 jilid 1. Jakarta: Erlangga.

Hartono, Jogiyanto. (2010). Metodologi Penelitian Bisnis: Salah Kaprah dan Pengalaman-Pengalaman. Edisi Pertama. BPFE. Yogyakarta.

Hegia Tarigan. 2014. Skripsi: Pengaruh Promosi Penjualan Terhadap Keputusan Pembelian Konsumen The Body Shop Outlet Bandung Indah Plaza,

Hermawan, Agus. 2012. Komunikasi Pemasaran. Jakarta:Erlangga

P.ISSN: 1410-7988 E.ISSN: 2614-123X 
Hermawan, Asep. 2013. Penelitian Bisnis. Universitas Trisakti, Jakarta.

Kotler, Philip. 2005. Manajemen Pemasaran. Jilid I, PT. Indeks Kelompok Gramedia, Jakarta.

Kotler, Philip \& Gary Amstrong. 2004. Dasar-dasar Pemasaran. Edisi 9 Jilid I, dialihbahasakan oleh Alexander Sindoro, Jakarta: Indeks.

Kotler, Philip \& Gary Amstrong. 2006. Principles of Marketing. New Jersey: Pearson International Edition.

Kotler, Philip \& Gary Amstrong. 2008. Prinsip-prinsip Pemasaran. Edisi 12. Jilid 1. Jakarta: Erlangga.

Kotler, Philip \& Kevin Lane Keller. 2009. Manajemen Pemasaran Edisi 13 Jilid 1. Penerbit Erlangga: Jakarta.

Kotler, Philip \& Keller, Kevin Lane. 2012. Marketing Management 14th Edition.New Jersey: Pearson Education,Inc.

Kotler, Philip \& Kevin Lane Keller, 2007. Manajemen Pemasaran. Jilid I. Edisi Kedua belas. PT. Indeks, Jakarta.

Kotler, Philip \& Kevin Lane Keller, 2008. Manajemen Pemasaran. Jilid I. Penerbit Erlangga: Jakarta.

Martono, Nanang. 2012. Metode Penelitian Kuantitatif Analisis Isi dan Analisis Data Sekunder. Jakarta : PT. Raja Grafindo Persada.

Mowen, Jhon C \& Michel Minor. 2009. Perilaku Konsumen. Edisi Kelima Jilid I.

Nengsih. 2011. Skripsi: Pengaruh Promosi Penjualan Terhadap Keputusan Menginap Di Hotel Kedaton Bandung.

Rambat, Lupiyoadi, \& A. Hamdani. 2006. Manajemen Pemasaran Jasa. Edisi Kedua. Jakarta: Salemba Empat.

Rinaldo Putra. 2015. Skripsi : Pengaruh Promosi Penjualan Terhadap Keputusan Pembelian Mebel Pada CV. Lautan Rezeki Pekanbaru.

Sangadji dan Sopiah. 2013. Perilaku Konsumen. Penerbit Andi. Yogyakarta.

Saputra, Hendra. 2008. Analisis Pengaruh Strategi Bauran Pemasaran Terhadap Keputusan Pembelian di Kota Medan. Universitas Sumatera Utara.
Sudarmanto R. G., 2005, Analisis Regresi Linier Ganda dengan SPSS, Edisi Pertama, Penerbit Graha Ilmu, Yogyakarta.

Sugiyono, (2008). Metode Penelitian Kunatitatif Kualitatif dan R\&D. Bandung Alfabeta.

Sugiyono. 2013. Metode Penelitian Pendidikan Pendekatan Kuantitatif, Kualitatif, dan R\&D. Bandung: Alfabeta.

Sumarwan, Ujang. 2004. Perilaku Konsumen Teori dan Penerapannya dalam Pemasaran. Cetakan kedua. Ghalia Indonesia. Bogor Selatan.

Supranto, J. 2009. Statistik Teori Dan Aplikasi. Edisi Ketujuh. Jilid 2. Erlangga. Jakarta.

Sutisna 2003. Perilaku Konsumen dan Komunikasi Pemasaran. Rosda Karya, Bandung.

Tjiptono, Fandy. 2008. Strategi Pemasaran. Edisi 3. Andi: Yogyakarta.

Zulaicha, Santri \& Irawati, Rusda. 2016. Pengaruh Produk Dan Harga Terhadap Keputusan Pembelian Konsumen Di Morning Bakery Batam 